\title{
Contribution of the hypothalamus and gut to weight gain susceptibility and resistance in mice
}

\author{
Barbara C Fam, Rebecca Sgambellone, Zheng Ruan, Joseph Proietto \\ and Sofianos Andrikopoulos
}

Department of Medicine (Austin Health), Austin Hospital, The University of Melbourne, Level 7, Lance Townsend Building, Studley Road, Heidelberg, Victoria 3084, Australia

\begin{abstract}
Obesity susceptibility in humans and in rodent strains varies in response to the consumption of high-energy density (HED) diets. However, the exact mechanism(s) involved in this susceptibility remain(s) unresolved. The aim of the present study was to gain greater insight into this susceptibility by using C57BL/6J (B6) mice that were separated into obesity-prone (diet-induced obese (DIO)) and obesity-resistant (diet-induced resistant (DR)) groups following an HED diet for 6 weeks. Physiological, biochemical and gene expression assessments of energy balance were performed in the DIO and DR mice on an HED diet and chow-fed mice. The increased weight gain of the DIO mice as compared to the DR mice was associated with increased energy intake and higher plasma leptin and adiponectin levels but not with reduced physical activity or resting energy expenditure. Hypothalamic Pomc gene expression was elevated, but there were no changes in Npy or Agrp expression. Adipose tissue leptin and adiponectin gene expression were significantly reduced in the DIO group as compared to the DR group. Interestingly, ileum expression of $\mathrm{G}$ protein-coupled receptor (Gpr) 40 (Gpr40) was significantly increased, whereas Gpr120, Gpr119, Gpr41, and glucagon-like peptide 1 (Glp1) were reduced. Contrastingly, the lower weight gain of the DR group was associated with elevated adipose tissue leptin and adiponectin gene expression, but there were no differences in plasma hormone or hypothalamic gene expression levels as compared to chow-fed mice. Therefore, the present data demonstrate that susceptibility and resistance to diet-induced weight gain in B6 mice appears to be predominantly driven by peripheral rather than hypothalamic modifications, and changes in gut-specific receptors are a potentially important contributor to this variation.
\end{abstract}

Correspondence should be addressed to S Andrikopoulos Email

sof@unimelb.edu.au
Journal of Endocrinology (2015) 225, 191-204

\section{Introduction}

Loss-of-function mutations in single genes have been linked to obesity in human subjects; however, such mutations only represent rare cases and cannot account for the overwhelming majority of obesity cases (O'Rahilly 2009). Genome-wide association studies have identified more than 40 loci related to human obesity, and the fat mass
Key Words

- diet-induced obesity

- high-energy density diet

- body weight regulation and obesity-associated (FTO) gene is the most replicated and shows the highest statistical significance (Marti \& Ordovas 2011). However, the combined effect of all of these loci only account for $2-3 \%$ of the inherited contribution to obesity risk (Marti \& Ordovas 2011), which highlights the multifactorial and complex nature of the disease. It is therefore

Published by Bioscientifica Ltd. 
generally accepted that 'common obesity' is driven by the sensitivity of an individual's genetic predisposition to the harmful effects of environmental influences, such as increased energy intake (particularly of high-energy density (HED) diets) and sedentary lifestyle.

It is clear from the continued rise in global obesity that we do not completely understand the mechanism(s) involved in its development, particularly seeing as the capacity for weight gain is not the same across our population. Inter-individual variability, particularly in response to an HED diet, can lead to excessive weight gain in those that are susceptible to these environments, whereas others can resist these effects and become only mildly overweight or remain lean (Levine et al. 1999, Ravussin \& Bouchard 2000, Blundell et al. 2005). Although this phenomenon is self-evident, it has been clinically demonstrated in a key study where lean, healthy individuals were overfed $1000 \mathrm{kcal}$ of energy daily for 8 weeks. This led to a large range in weight gain, which was subsequently attributed to the activation of an element of energy expenditure, non-exercise activated thermogenesis (NEAT); the individuals that gained more weight exerted less NEAT and those that remained lean exerted increased NEAT (Levine et al. 1999). However, this is only one study that showed a potential mechanism for this diversity; it is still unclear what biochemical/genetic mechanisms contribute to this phenomenon.

Rodent models of obesity are an ideal tool for studying human obesity, not only because they present with the same physiological responses in terms of appetite, energy expenditure and fat deposition profiles but also because they exhibit the same pattern of weight gain divergence in response to HED diets (Chang et al. 1990, Pagliassotti et al. 1994, Levin et al. 1997, Levin \& Dunn-Meynell 2000, 2002, Burcelin et al. 2002). Outbred strains, such as SpragueDawley (SD) and Wistar rats, have reported several physiological explanations for obesity susceptibility and resistance, including changes in energy intake, wholebody fat oxidation and pancreatic sympathetic tone (Levin et al. 1987, Chang et al. 1990), whereas increases in circulating leptin, insulin and cholecystokinin and reductions in ghrelin have been reported to contribute to the separation in SD rats (Li et al. 2011). Similarly, the inbred C57BL/6J (B6) mouse model can be divided into susceptible and resistant populations, with some authors reporting that changes in the appetite stimulators neuropeptide Y (Npy) and agouti related peptide (Agrp) and in the appetite-suppressing melanocortin pathway (Huang et al. 2003a,b) were the predominant contributors, whereas other authors showed changes only in the suppressor of cytokine signalling 3 (Socs3) but not in Npy or Agrp (Enriori et al. 2007). Although there has been some effort to explore the mechanisms that underpin this body weight variance in the outbred models, the current literature has only provided a little insight into these potential mechanisms, and they remain poorly understood. We hypothesise that the cause of diet-induced obesity (or resistance) is mediated by changes in the hypothalamic neuropeptides that govern appetite/satiety.

In the present study, we sought to gain a better understanding of these mechanisms by utilising the $\mathrm{B} 6$ mouse model and performing a more detailed analysis of the physiological and genetic factors (hypothalamic and gut) that govern body weight following 6 weeks on an HED diet.

\section{Materials and methods}

\section{Mice and diets}

Four-week-old female C57BL/6J (B6) mice were purchased from the Walter and Eliza Hall Animal Facility (Parkville, Vic., Australia) and individually housed at the BioResources Facility, Austin Health (Heidelberg, Vic., Australia), where they were subjected to a controlled $12 \mathrm{~h}$ light:12 $\mathrm{h}$ darkness lighting cycle (darkness started at $\sim 1900 \mathrm{~h}$ ) and a room temperature of $22^{\circ} \mathrm{C}$. After 1 week of acclimatisation, the animals were weight-matched into groups (to control for potential maternal influences). One-third were fed a standard rodent chow diet (9\% fat $(\mathrm{w} / \mathrm{w})(25 \%$ energy), $22 \%$ protein $(\mathrm{w} / \mathrm{w})(26 \%$ energy) and $69 \%$ carbohydrate $(\mathrm{w} / \mathrm{w})$ (49\% energy); $13.2 \mathrm{~kJ} / \mathrm{kg}$ total energy, Ridley AgriProducts, Pakenham, Vic., Australia), and the remaining mice were fed a modified version of the sweetened condensed milk diet used by Levin (Levin et al. 1997, Levin \& Dunn-Meynell 2000) (HED diet; 15\% fat $(\mathrm{w} / \mathrm{w})(31 \%$ energy), $19 \%$ protein $(\mathrm{w} / \mathrm{w})(17 \%$ energy) and $57 \%$ carbohydrate $(\mathrm{w} / \mathrm{w})(51 \%$ energy); $18.6 \mathrm{~kJ} / \mathrm{g}$ total energy, Speciality Feeds, SF08-044, Glen Forrest, WA, Australia). Mice were allowed to feed ad libitum during the experimental period. Sample collections were standardised and performed at the same time of the day (0900-1100 h) as described in the following sections for all of the groups. Experimental procedures were carried out in accordance with the protocols approved by the Austin Health Animal Ethics Committee (AEC no. A2010/04028).

\section{Feeding protocol and energy balance measurements}

Body weight and food intake were determined weekly (Wong et al. 2011). After 4 weeks of feeding, mice were

Published by Bioscientifica Ltd. 
stratified based on body weight gain into diet-induced obese (DIO; mice that gained equal to or greater than the average of the HED-fed group) and diet-induced resistant (DR; mice that maintained a similar weight gain pattern as that of the chow-fed only B6 mice) groups. Mice that fell between these groups ( $n=11$, or $\sim 20 \%$ of the mice on the high-fat (HF) diet) were not used, which was in line with other studies that have used similarly stratified $\mathrm{B} 6$ groups (Huang et al. 2003a,b, Enriori et al. 2007). Mice were tracked for a further 2 weeks on their respective diets. During the 6th week of feeding, voluntary physical activity (individually housed running wheels, which have been shown to correlate well with infrared photoelectric measurements of spontaneous motor activity (Thorburn et al. 2000)), resting energy expenditure (REE) and respiratory quotient (RQ; indirect calorimetry; $10 \mathrm{~min}$ interval sampling over 75 min during the resting period (daytime)) were measured (Fam et al. 2007, Mangiafico et al. 2011, Wong et al. 2011, Visinoni et al. 2012). At the conclusion, mice were anaesthetised in the non-fasted state (0900 h) (Ahren \& Scheurink 1998, Fam et al. 2007) with an i.p. injection of sodium pentobarbitone, and blood was collected via cardiac puncture (0900-1100 h). Brain and gut ilea were rapidly removed and frozen in liquid nitrogen. Fat depots (subcutaneous, infra-renal, gonadal white fat (WAT) and brown fat (BAT)) were excised, weighed and frozen in liquid nitrogen. All tissues were stored at $-80^{\circ} \mathrm{C}$.

\section{Plasma hormone concentrations}

Samples were immediately added to EDTA-coated tubes that contained $10 \mu \mathrm{l}$ of protease inhibitors per $1 \mathrm{ml}$ of blood (100X stock containing Pefabloc (Roche, cat. no. 11429868001), DPPIV inhibitor (Millipore, cat. no. DPP4010; Bayswater, Victoria, Australia) and protease inhibitor cocktail (Sigma, cat. no. P2714)). Plasma was collected and stored at $4{ }^{\circ} \mathrm{C}$ for the measurement of leptin, adiponectin (total) and ghrelin (acylated) (one assay using the Mouse Gut Hormone MILLIplex kit, Millipore), insulin (mousespecific ELISA; 80-INSMS-E01, ALPCO Diagnostics, Salem, $\mathrm{NH}, \mathrm{USA}$ ) and glucose (Analox Glucose Analyser; Helena Laboratories Pty Ltd, Melbourne, Vic., Australia).

\section{Hypothalamic dissection and RNA/cDNA preparation}

Whole hypothalami were dissected, and the sections that contained the arcuate nuclei (ARC) were excised, as previously reported (Steinberg et al. 2006, Fam et al. 2007, Wong et al. 2011, Visinoni et al. 2012). Sections that contained the paraventricular nuclei (PVN) were also collected to act as a site-specific control for gene expression. RNA and cDNA were prepared from hypothalamic sections and dissected tissues (Fam et al. 2007, 2012, Wong et al. 2011, Visinoni et al. 2012).

\section{Gene expression profiling}

Gene-specific Taqman Gene Expression Assays (Applied Biosystems, Scoresby, Victoria, Australia) were used to analyse mRNA expression levels of the genes listed in Supplementary Table 1, see section on supplementary data given at the end of this article, according to the manufacturer's protocol. A PerkinElmer ABI Prism 7700 Sequence Detector and Sequence Detection Systems Software version 1.9.1 (Applied Biosystems) was used for detection, and the results were analysed with the $2\left(-\Delta \Delta C_{\mathrm{T}}\right)$ method, which is based on relative quantification of the treated group to the untreated group (Wong et al. 2011).

\section{Microarray analysis}

Microarray analysis was performed only in ARC samples from chow-fed, DIO and DR mice by the Australian Genome Research Facility (AGRF) with the Illumina Mouse WG-6 v2.0 BeadArray. This array uses 45281 probe sets that measure the gene expression of 26766 well-established coding transcripts, 6856 provisional annotated coding transcripts and 56 well-established noncoding transcripts, all of which come from the Mouse RefSeq Rel 22 content. In addition, the chips are supplemented with probes that target the mouse exonic evidencebased oligonucleotide set (MEEBO) and the exemplar protein coding sequences (RIKEN FANTOM24-6). Between 1 and $2 \mu \mathrm{g}$ of total RNA from ARC samples of the chow-fed, DIO and DR mice were extracted. DNAse was treated and cleaned post-extraction using the RNeasy MiniKit (Qiagen). Samples were analysed by AGRF and were normalised using R-Bioconductor Software (www. bioconductor.org) and Partek Genomic Suite Software (for ANOVA analysis; Partek, Inc., St Louis, MO, USA).

\section{Statistical analysis}

All data are presented as means \pm s.E.M. using GraphPad Prism 5 for Windows (GraphPad Software, Inc., La Jolla, CA, USA). Statistical comparisons between single parameters were made using one-way ANOVA analysis (Minitab 15, 2007; Sydney, NSW, Australia). For repeated measures, a general linear model (GLM) ANOVA was used

Published by Bioscientifica Ltd. 
for comparison, and Tukey's post hoct-test was used to determine significance (Minitab 16.1.10, 2010). Significance was set at $P<0.05$.

\section{Results}

\section{Body weight and adiposity characteristics}

DIO mice were significantly heavier than both DR and chow-fed mice from week 3 until week $6(P<0.05)$, whereas DR and chow-fed mice maintained similar body weights over the same time period (Fig. 1A). When body weight gain was calculated (Fig. 1B), DIO mice consistently gained more weight on the HED diet than did the DR mice on the same diet and the chow-fed mice $(P<0.005)$, and this weight gain was associated with increased adiposity across all of the fat depots $(P<0.05$, Fig. 1C). DR mice had lower body weight gain as compared to chow-fed mice (Fig. 1B), and this was associated with similar subcutaneous and BAT masses and increased infrarenal and gonadal masses $(P<0.05$, Fig. $1 C)$, which reflected the increased fat intake of the DR mice.

\section{Energy balance characteristics}

DIO mice consumed significantly more food as compared to both DR and chow-fed mice (chow-fed: 3.76 \pm 0.05 , DR: $3.60 \pm 0.20$, DIO: $4.66 \pm 0.44, \mathrm{~g} /$ day; $P<0.05$ DIO vs chowfed and DR mice), but there was no difference between DR and chow-fed mice. With respect to energy intake, DIO mice still consumed more kilojoule than DR and chow-fed mice did $(P<0.05$, Fig. 2A). DR mice consumed more kilojoule than the chow-fed mice did $(P<0.05)$ because of the increased energy density of the diet.
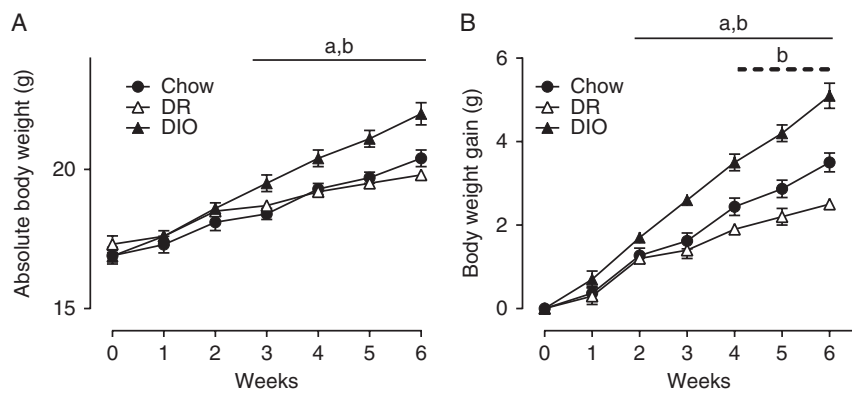

Figure 1

Absolute body weights ( $g$ ) (A), body weight gain (g/day) and average body weight gain over 6 weeks (B) in female B6 mice fed either a chow diet (Chow) or an HED diet and stratified into diet-induced obese (DIO) and diet-induced resistant (DR) groups over 6 weeks of feeding. (C) Absolute fat pad mass (g) from individual white adipose tissue depots (subcutaneous,
There were no significant differences in voluntary physical activity (Fig. 2B) or daytime REE (Fig. 2C) among the groups. Similarly, there was no significant preference for either fat or carbohydrate as a nutrient source among the groups as assessed by RQ (Fig. 2D) or when calculated as a rate of oxidation (fat oxidation, chow-fed: $50.95 \pm$ 5.68, DR: $49.33 \pm 2.80$, DIO: $47.45 \pm 4.00$; glucose oxidation chow-fed: $24.98 \pm 5.89$, DR: $17.51 \pm 2.13$, DIO: $15.07 \pm 2.65, P>0.05)$.

\section{Plasma hormone levels}

Non-fasted plasma insulin (Fig. 3A) was significantly elevated in the DIO mice as compared to the DR and chow-fed mice, yet glucose levels (Fig. 3B) were lower in both the DIO and DR groups as compared to the chow-fed mice. Plasma leptin (Fig. 3C) was, as expected, higher in the DIO group, and interestingly, plasma adiponectin was also significantly elevated as compared to both the DR and chow-fed mice (Fig. 3D). Plasma ghrelin, the main circulating appetite-stimulating hormone, was not different between the DIO and DR groups, but it was statistically lower in DIO as compared to chow-fed mice (Fig. 3E).

\section{Hypothalamic ARC neuropeptide gene expression}

To determine if changes in the expression of hypothalamic neuropeptides were associated with physiological differences, we assessed ARC gene expression of the orexigenic neuropeptides Npy and Agrp, the anorexigenic pro-hormone Pomc and a marker of leptin insensitivity, Socs3. Npy (Fig. 4A) and Agrp (Fig. 4B) mRNA levels were not significantly different between the groups. Pomc mRNA

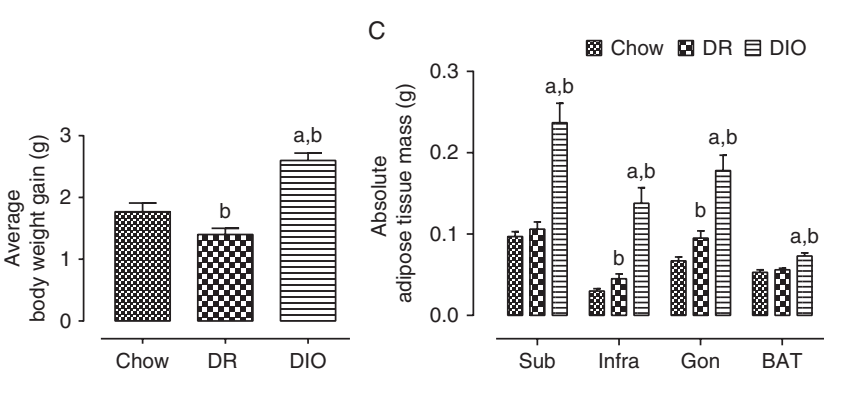

infra-renal and gonadal) and total brown adipose tissue (BAT) from Chow, DR and DIO groups. Results are presented as means \pm s.E.M. $(n=20-24$ per group). ${ }^{a} P<0.005$ vs $D R ;{ }^{b} P<0.005$ vs Chow (one-way ANOVA for single parameters and GLM ANOVA for repeated measurements). Sub, subcutaneous; Infra; infra-renal; Gon, gonadal.

Published by Bioscientifica Ltd 
A
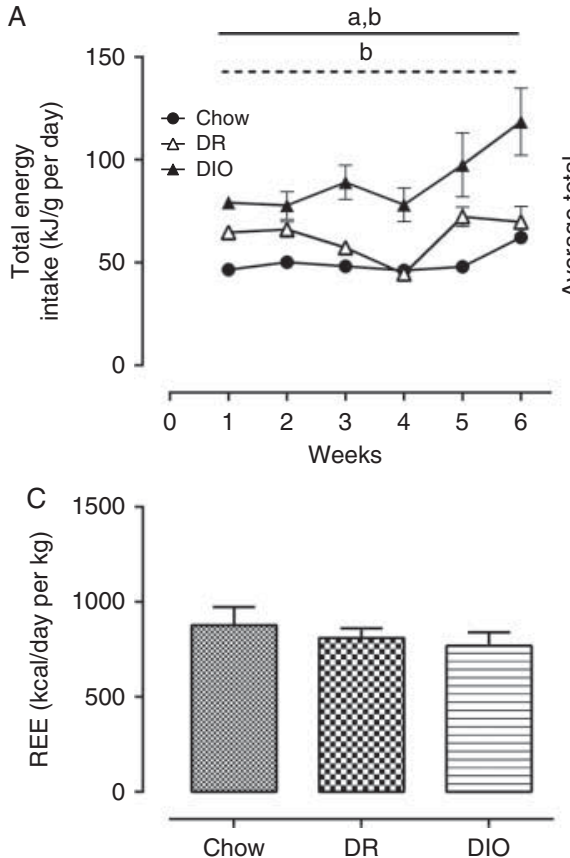

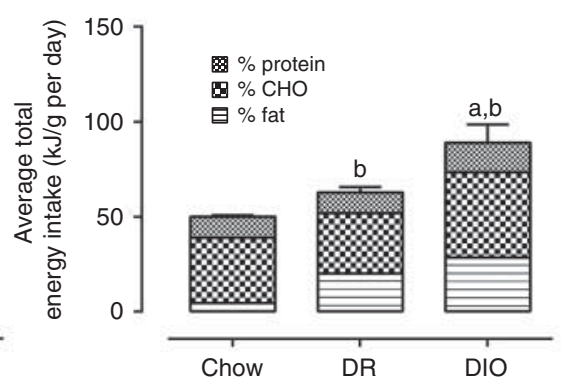

B

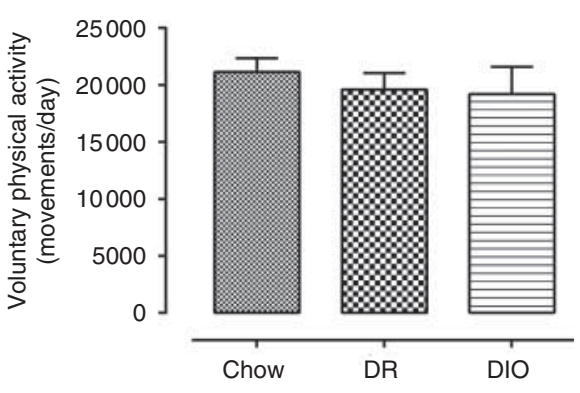

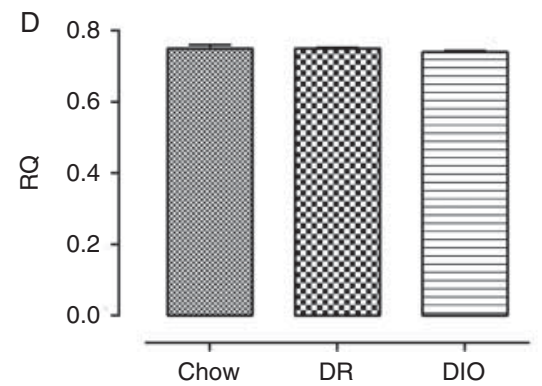

Figure 2

(A) Daily total energy intake ( $\mathrm{kJ} / \mathrm{g}$ per day) in female B6 mice fed either a chow diet (Chow) or an HED diet and stratified into diet-induced obese (DIO) and diet-induced resistant (DR) groups over 6 weeks of feeding. The inset panel shows the average energy intake over 6 weeks in the Chow, DR and DIO groups. (B) Physical activity (revolutions/day) as measured by wheel running in Chow, DR and DIO groups after 6-7 weeks of feeding. (C) Resting energy expenditure (REE; kcal/day per kg) as measured by

levels, however, were significantly elevated in the DIO mice as compared to the DR and chow-fed mice $(P<0.05$, Fig. 4C). Socs3 mRNA levels (Fig. 4D) were not significantly different between any of the groups. PVN sections showed no difference among the groups in any of the genes measured, and levels were significantly lower in these sections as compared to the ARC sections (data not shown).

\section{Hypothalamic ARC microarray analysis}

Microarray comparisons with significant changes of $\geq 1.25$-fold revealed a total of 101 differentially expressed (DE) genes between the DIO and DR groups (85 up and 16 down in the DIO group); 60 DE genes between the DIO and chow-fed groups (26 up and 34 down in the DIO group); and $188 \mathrm{DE}$ genes between the DR and chow-fed groups (12 up and 176 down in the DR group). The gene ontologies of these DE genes within each comparison are presented in Supplementary Tables 2, 3 and 4, see section on supplementary data given at the end of this article and are separated into biological processes, cellular components and molecular functions. Genes that indirect calorimetry in Chow, DR and DIO groups after 6 weeks of feeding. (D) Respiratory quotient (RQ) levels in Chow, DR and DIO groups after 6 weeks of feeding. Results are presented as means \pm s.E.M. $(n=11-24$ per group for food intake and energy intake measurements, and $n=4$ for energy expenditure measurements). ${ }^{a} P<0.005$ vs $D R ;{ }^{b} P<0.005$ vs Chow (one-way ANOVA for single parameters and GLM ANOVA for repeated measurements).

were deemed to be potential candidates and were unique within each comparison (i.e. not shared with the other comparisons) are shown in Tables 1 and 2 (DIO and DR) and in Supplementary Tables 5 (DIO and chow-fed) and 6 (DR and chow-fed). Of these, 58 genes were regulated between the DIO and DR mice (46 genes up and 12 genes down in the DIO group); 44 genes were regulated between the DIO and chow-fed mice (19 genes up and 25 genes down in the DIO group); and 112 genes were regulated between the DR and chow-fed mice (nine genes up and 103 genes down in the DIO group). All data available online at: https://lims.agrf.org.au/ClientSubmission/ Logon.aspx.

\section{White adipose tissue gene expression}

To determine if WAT gene changes were associated with physiological differences, we measured mRNA expression of leptin, adiponectin and the pro-inflammatory marker Tnf $\alpha$ in each fat depot. Leptin mRNA expression was not significantly different among the groups in either subcutaneous or gonadal fat (Fig. 5A). However, there was a

Published by Bioscientifica Ltd 

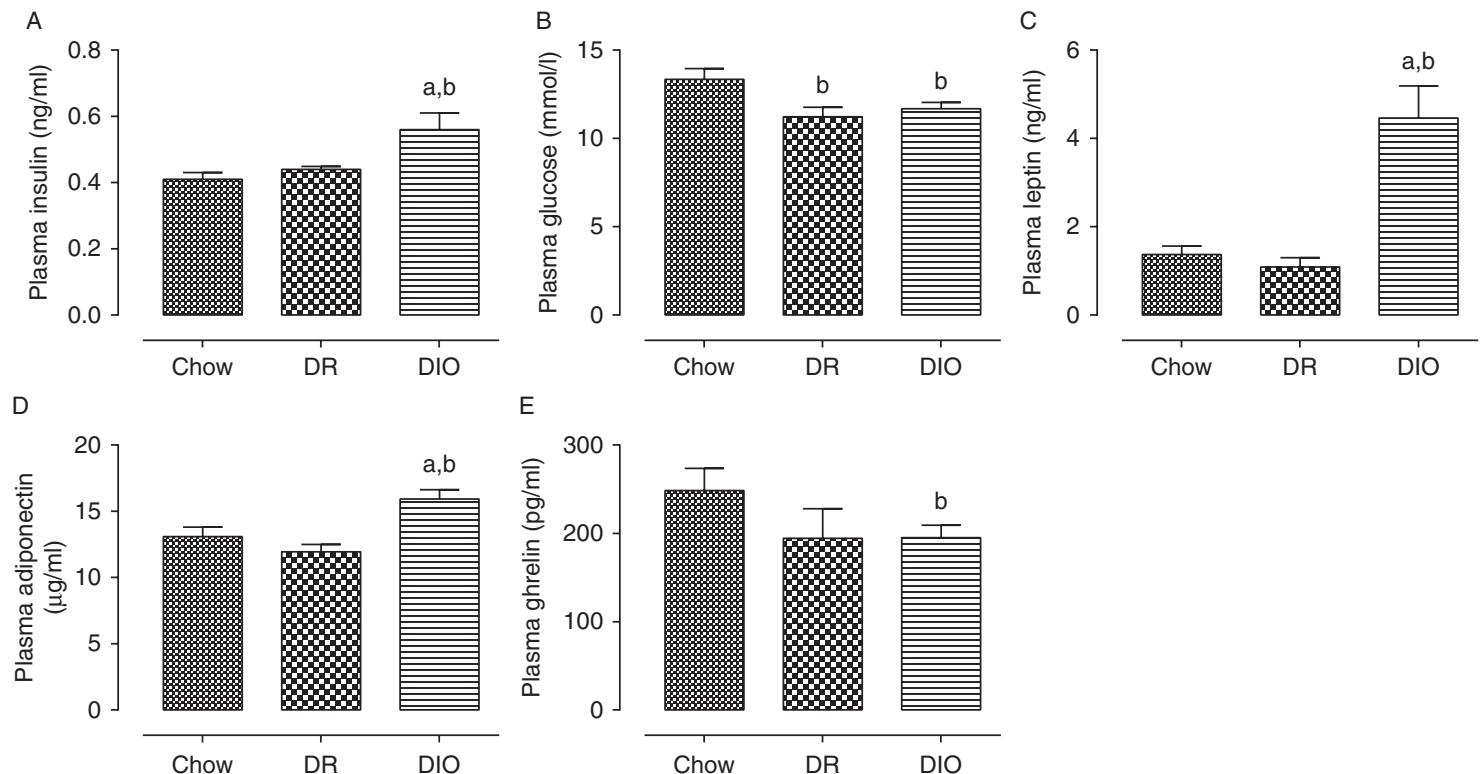

Figure 3

Non-fasted plasma levels of insulin (A), glucose (B), leptin (C), adiponectin (D) and ghrelin (E) in Chow, DR and DIO groups after 6 weeks of feeding. Results are presented as means \pm s.E.M. ( $n=14-20$ per group). ${ }^{\mathrm{a}} P<0.005$ vs $\mathrm{DR} ;{ }^{\mathrm{b}} P<0.005$ vs Chow (one-way ANOVA).

significant reduction in the infra-renal depot of DIO as compared to DR mice but not as compared to chow-fed mice. Moreover, DR mice had significantly elevated infrarenal leptin mRNA expression as compared to chow-fed mice $(P<0.05)$. Adiponectin mRNA expression (Fig. 5B) showed DIO mice trending towards reduced expression in the subcutaneous fat as compared to both DR and chow-fed mice ( $P=0.09$ for both), but it was significantly reduced in the gonadal depot $(P<0.05)$. Infra-renal adiponectin expression was not different between the DIO and chowfed mice; however, DR mice had significantly elevated levels as compared to both groups $(P<0.05)$. Subcutaneous and infra-renal but not gonadal $T n f \alpha$ expression was significantly reduced in DIO mice relative to DR and
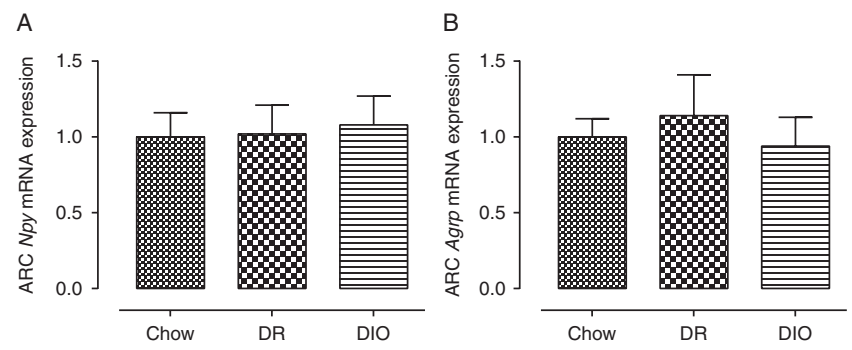

Figure 4

Central mRNA expression levels of Npy (A), Agrp (B), Pomc (C) and Socs3 (D) in ARC samples from Chow, DR and DIO groups after 6 weeks of feeding. $R n 18 s$ was used as the housekeeping gene. Results are presented as chow-fed mice $(P<0.05)$, but no differences were seen between DR and chow-fed mice in any fat depot.

\section{Ileum gene expression}

To determine if DIO and DR mice have differential expression patterns in genes involved in fatty acidinduced gut peptide secretion, we measured the fatty acid-specific $\mathrm{G}$ protein-coupled receptors $(\mathrm{GPr})$ and glucagon-like peptide 1 (Glp1) mRNA in gut ileum. Glp1 mRNA expression was significantly reduced in DIO mice as compared to both DR and chow-fed mice (Fig. 6A), whereas DR mice had the same expression level as chowfed mice. When GPR gene levels were assessed, DIO mice
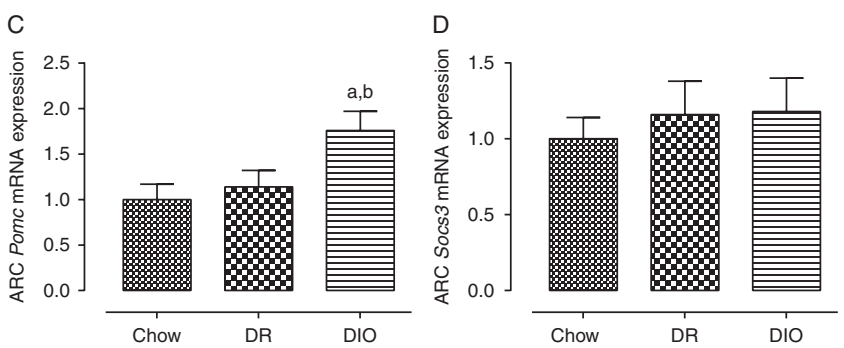

means \pm s.E.M. ( $n=8-13$ per group) relative to Chow mice. ${ }^{a} P<0.005$ vs $D R_{\text {; }}$ ${ }^{\mathrm{b}} \mathrm{P}<0.005$ vs Chow (one-way ANOVA).

Published by Bioscientifica Ltd 
Table 1 Summary of hypothalamic ARC genes up-regulated $\geq 1.25$-fold in DIO mice as compared to DR mice ( $n=4$ per group)

\begin{tabular}{|c|c|c|c|}
\hline Gene $^{a}$ & Gene name & Fold change & $P$ value \\
\hline Zfp533 & Zinc finger protein 533 & 1.624 & 0.046 \\
\hline Arrdc3 & Arrestin domain containing 3 & 1.576 & 0.026 \\
\hline Etv1 & Ets variant 1 & 1.517 & 0.033 \\
\hline Grm5 & Glutamate receptor, metabotropic 5 & 1.517 & 0.020 \\
\hline Mal & Myelin and lymphocyte protein, $\mathrm{T}$ cell differentiation protein & 1.505 & 0.041 \\
\hline Trim59 & Tripartite motif-containing 59 & 1.477 & 0.019 \\
\hline S/c44a1 & Solute carrier family 44 , member 1 & 1.472 & 0.037 \\
\hline B230208H17Rik & RAB, member RAS oncogene family-like 6 & 1.446 & 0.046 \\
\hline LOC227393 & Predicted gene 1833 & 1.425 & 0.040 \\
\hline Prr18 & Proline rich 18 & 1.411 & 0.014 \\
\hline Papola & Poly (A) polymerase $\alpha$ & 1.388 & 0.044 \\
\hline scl0o01118.1_0 & & 1.388 & 0.012 \\
\hline Chd 2 & Chromodomain helicase DNA binding protein 2 & 1.388 & 0.014 \\
\hline Sox10 & SRY (sex determining region Y)-box 10 & 1.377 & 0.027 \\
\hline Actb & Actin, $\beta$ & 1.369 & 0.017 \\
\hline Ppargc1b & Peroxisome proliferative activated receptor, $\gamma$, coactivator $1 \beta$ & 1.369 & 0.045 \\
\hline scl0002785.1_49 & & 1.366 & 0.046 \\
\hline Zmiz1 & Zinc finger, MIZ-type containing 1 & 1.344 & 0.039 \\
\hline BC017647 & Family with sequence similarity 222 , member B & 1.342 & 0.004 \\
\hline KIf4 & Kruppel-like factor 4 (gut) & 1.340 & 0.030 \\
\hline Mpp5 & $\begin{array}{l}\text { Membrane protein, palmitoylated } 5 \text { (MAGUK p55 } \\
\text { subfamily member 5) }\end{array}$ & 1.328 & 0.003 \\
\hline Irs2 & Insulin receptor substrate 2 & 1.317 & 0.013 \\
\hline Mcph1 & Microcephaly, primary autosomal recessive 1 & 1.308 & 0.031 \\
\hline Tle1 & $\begin{array}{l}\text { Transducin-like enhancer of split 1, homolog of Drosophila } \\
\text { E(spl) }\end{array}$ & 1.304 & 0.034 \\
\hline Ttc3 & Tetratricopeptide repeat domain 3 & 1.297 & 0.007 \\
\hline Sypl & Synaptophysin-like protein & 1.295 & 0.014 \\
\hline Ank2 & Ankyrin 2 , brain & 1.295 & 0.037 \\
\hline LOC331507 & Predicted gene 1866 & 1.294 & 0.029 \\
\hline BC057371 & Ribosomal modification protein rimK-like family member $\mathrm{A}$ & 1.287 & 0.005 \\
\hline$A / 314180$ & Expressed sequence $\mathrm{Al} 314180$ & 1.284 & 0.028 \\
\hline Foxq1 & Forkhead box Q1 & 1.283 & 0.032 \\
\hline$B b x$ & Bobby sox homolog (Drosophila) & 1.282 & 0.018 \\
\hline Kcnma1 & $\begin{array}{l}\text { Potassium large conductance calcium-activated channel, } \\
\text { subfamily } M, \alpha \text { member } 1\end{array}$ & 1.281 & 0.040 \\
\hline Lhfp/3 & Lipoma HMGIC fusion partner-like 3 & 1.278 & 0.049 \\
\hline Riok1 & RIO kinase 1 (yeast) & 1.276 & 0.032 \\
\hline Al427122 & Plastin 1 (I-isoform) & 1.273 & 0.048 \\
\hline Pvrl3 & Poliovirus receptor-related 3 & 1.271 & 0.008 \\
\hline Gsk3b & Glycogen synthase kinase $3 \beta$ & 1.269 & 0.023 \\
\hline 5830415L20Rik & Family with sequence similarity 133 , member $B$ & 1.267 & 0.024 \\
\hline S/c12a2 & Solute carrier family 12 , member 2 & 1.267 & 0.027 \\
\hline Tmem184c & Transmembrane protein $184 \mathrm{C}$ & 1.265 & 0.018 \\
\hline Setd8 & SET domain containing (lysine methyltransferase) 8 & 1.264 & 0.027 \\
\hline Insc & Inscuteable homolog (Drosophila) & 1.262 & 0.046 \\
\hline Map2k2 & Mitogen-activated protein kinase kinase 2 & 1.261 & 0.036 \\
\hline Slc35b1 & Solute carrier family 35 , member B 1 & 1.253 & 0.037 \\
\hline Bace1 & $\beta$-site APP cleaving enzyme 1 & 1.251 & 0.0005 \\
\hline
\end{tabular}

${ }^{\mathrm{a}} \mathrm{Genes}$ of interest are in red font.

displayed significantly more Gpr40 mRNA expression than both DR and chow-fed mice (Fig. 6B), and Gpr120 (Fig. 6C) was significantly lower as compared to DR and chow-fed mice. Similar levels were observed between the latter two groups. In contrast, Gpr119 expression was reduced in both DIO and DR mice as compared to chow-fed, with DIO mice displaying an even more marked reduction as compared to DR mice ( $P<0.05$, Fig. 6D). Similarly, Gpr41 was also reduced in both the DIO and DR groups relative to the chow-fed group and also a greater reduction in the DIO vs the DR group (Fig. 6E). Gpr43 only showed a trend for reduced expression in the DIO group as compared to the DR group ( $P=0.07$, Fig. $6 \mathrm{~F})$, but there was a significant reduction as compared to the chow-fed group. 
Table 2 Summary of hypothalamic ARC genes down-regulated $\geq-1.25$-fold in DIO mice as compared to DR mice

\begin{tabular}{l} 
Gene \\
\hline 1700001 C02Rik \\
Gm1673 \\
1700027A23Rik \\
9030607L17Rik \\
Slc6a7 \\
Bola2 \\
Rarres2 \\
LOC623121 \\
Ppm1f \\
Nme5 \\
3010026009 Rik \\
Lhb
\end{tabular}

\begin{tabular}{l} 
Gene name \\
\hline RIKEN CDNA $1700001 \mathrm{C} 02$ gene \\
Predicted gene 1673 \\
Primary cilia formation \\
IZUMO family member 4 \\
Solute carrier family 6 (neurotransmitter transporter, \\
I-proline), member 7 \\
BolA-like 2 (E. coli) \\
Retinoic acid receptor responder (tazarotene induced) 2 \\
PREDICTED: similar to Interferon-activatable protein 203 \\
(Ifi-203) (interferon-inducible protein p203) \\
protein phosphatase $1 \mathrm{~F}$ (PP2C domain containing) \\
NME/NM23 family member 5 \\
RIKEN CDNA 3010026O09 gene \\
Luteinizing hormone $\beta$
\end{tabular}

\begin{tabular}{c}
\hline Fold change \\
\hline-1.366 \\
-1.331 \\
-1.325 \\
-1.316 \\
-1.313 \\
-1.313 \\
-1.311 \\
-1.278 \\
-1.271 \\
-1.257 \\
-1.253 \\
-1.250
\end{tabular}

\begin{tabular}{c}
\hline $\boldsymbol{P}$ value \\
\hline 0.011 \\
0.035 \\
0.016 \\
0.037 \\
0.040 \\
0.043 \\
0.012 \\
0.015 \\
0.031 \\
0.032 \\
0.048 \\
0.014
\end{tabular}

\section{Discussion}

Despite many years of effort, the mechanisms involved in the variability of body weight gain in response to an energyrich diet remain unresolved. By using the C57BL/6J (B6) mouse strain, the present study has endeavoured to make further inroads into this understanding. Whereas others have shown this weight gain variability predominantly in male B6 mice (Huang et al. 2003a,b, Enriori et al. 2007, Peyot et al. 2010), the present study demonstrated the same phenomenon within a female population. Although reports have suggested that energy expenditure increases with obesity development (Leibel et al. 1995, MacLean et al. 2004), we showed no evidence of such changes at either a physical activity or an REE level to account for this group variance. However, because we did not directly measure NEAT (or fidgeting) in our mice, it may still be possible that this component could contribute to the variation, given the previous evidence from Levine et al. (1999) which demonstrated the importance of NEAT in weight gain responses to increased energy loads. Nonetheless, based on the present results, energy intake appears to be the major contributor to this weight gain difference in $\mathrm{B} 6$ mice.

Hypothalamic gene alterations, particularly in the ARC, have been suggested to be responsible for obesity susceptibility and resistance, particularly because of its critical role in appetite regulation (Huang et al. 2003a,b, Enriori et al. 2007). However, the present gene expression analysis showed that neither of the major orexigenic neuropeptides (Npy or Agrp) were different between the DIO and DR mice; this finding contrasts earlier studies (Huang et al. 2003a,b). Even the expression of Socs3, a factor involved in central leptin insensitivity (a potential mechanism for obesity susceptibility), which was shown previously to be up-regulated in a similar B6 DIO cohort (where Npy and Agrp expression was unchanged) (Enriori et al. 2007), was unaltered in the present model. Differences in dietary composition could be a contributing factor, with our diet being rich in sweetened condensed milk-based fatty acids and fructose (Levin et al. 1997) compared to the others which were coconut and sunflower oil based (Huang et al. 2003a,b), as well as the fact that we used female mice, whereas previous reports have used males. In this respect, it is important to highlight the differences in fat distribution following HF feeding between the sexes: male mice deposit fat in all of the depots (Funkat et al. 2004), whereas female mice preferentially gain subcutaneous fat (Fig. 1C). Indeed, we were surprised to find that Pomc, the major melanocortin pathway precursor involved in appetite suppression, was significantly elevated in the present DIO mice. Although it is paradoxical, this has been reported previously in other HF fed mouse models (Ziotopoulou et al. 2000, Torri et al. 2002). We speculate that this up-regulation of the melanocortin pathway is meant to produce more of the active product, $\alpha-\mathrm{MSH}$, in an attempt to suppress the excess energy intake and to limit weight gain in DIO mice. However, the mice are clearly unresponsive. Defects downstream from Pomc (splicing into $\alpha$-MSH or melanocortin 4 receptor expression/ function defects) may account for this failure to regulate, although we did not directly measure these in the present study. Interestingly, the DR mice had similar neuropeptide expression as that of the chow-fed control mice, which indicates that hypothalamic changes are not associated with weight gain resistance. It is important to note that we did not assess protein levels to verify the gene expression data. Nevertheless, our findings imply that the known key regulators in the ARC may not directly contribute to the differences between DIO and DR mice and that the

Published by Bioscientifica Ltd. 
A
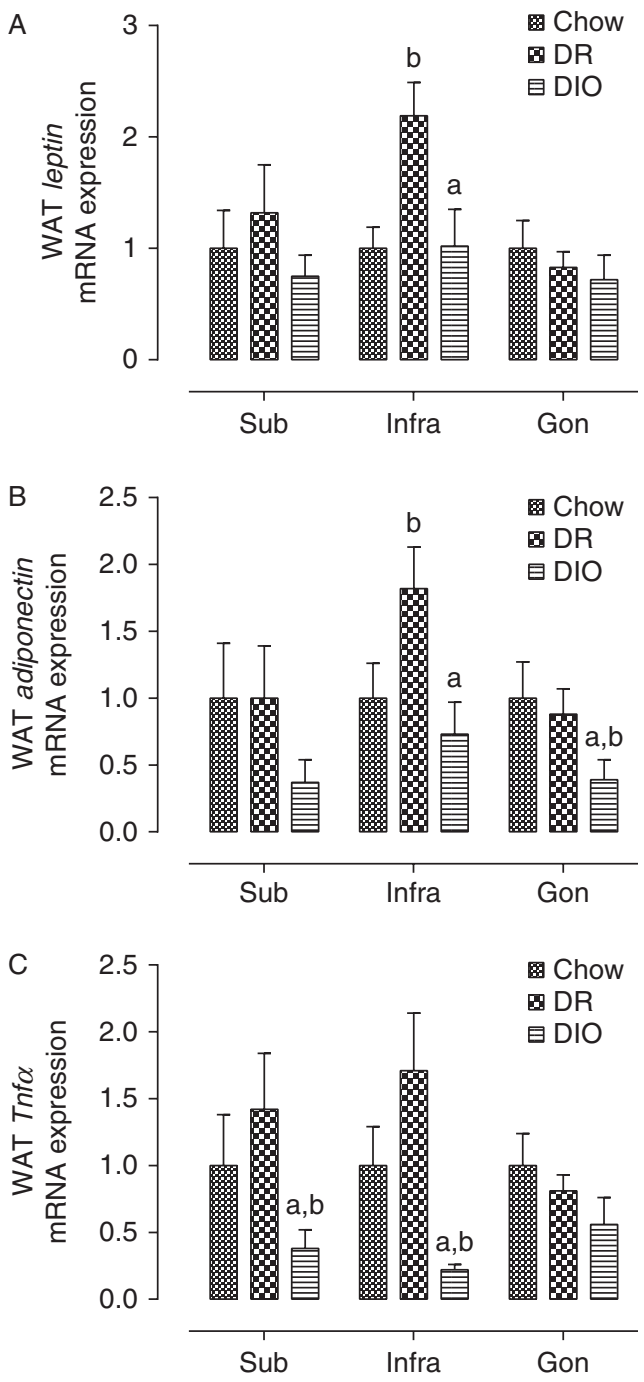

Figure 5

Peripheral mRNA expression levels of leptin (A), adiponectin (B) and Tnf $\alpha$ (C) in subcutaneous, infra-renal and gonadal WAT depots from Chow, DR and DIO groups after 6 weeks of feeding. Rn18s was used as the housekeeping gene. Results are presented as means \pm s.E.M. ( $n=8-13$ per group) relative to Chow mice. ${ }^{a} P<0.05$ vs $D R ;{ }^{b} P<0.05$ vs Chow (one-way ANOVA). Sub, subcutaneous; Infra, infra-renal; Gon, gonadal.

changes in DIO mice may be consequential rather than causative.

This surprising finding led us to perform microarray analysis in ARC samples of the mice to identify other genes that may be differentially regulated. A comparison between DIO and DR identified 58 genes in total, whereas a comparison with the chow-fed group highlighted 44 genes in the DIO and 112 genes in the DR group. This suggests that the susceptibility to diet-induced obesity is associated with a smaller number of ARC gene changes, whereas resistance to weight gain and maintaining the same level of body weight as the chow-fed group requires a larger number of genes to be DE. Of the candidates identified in the DIO/DR screen, several have previously been implicated in obesity development in both human subjects and in mouse models. Specifically, the arrestin domain containing three gene $(A r r d c 3)$ (up-regulated 1.6fold in the present DIO mice) has been shown through genome-wide association scans (GWAS) to be positively associated with increased BMI in human obesity and to play a primary role in adipose tissue in regulating energy expenditure (Patwari et al. 2011). Mice deficient in this gene have an obesity resistance phenotype via its positive effects on physical activity and thermogenesis (Patwari et al. 2011). Peroxisome proliferative activated receptor, $\gamma$, coactivator $1 \beta$ (PPARGC1 $\beta$, or PGC-1 $\beta$ ) has also been positively associated with obesity development in humans through the existence of at least 20 single nucleotide variants in its coding region (Andersen et al. 2005), and it has been found to be highly expressed in tissues such as skeletal muscle, BAT, heart and brain (Meirhaeghe et al. 2003). The present DIO mice indicate an $\sim 1$.4-fold increase in the expression of Ppargc $1 \beta$ as compared to DR mice. Glycogen synthase 3 kinase $\beta$ (Gsk3 $\beta$ ) was also found to have a significant difference between the DIO and the DR mice (about 1.3-fold in favour of the DIO mice). Although it has more commonly been found in skeletal muscle to inhibit cellular responses to insulin, this gene has also been found to be present in neural tissues (Clodfelder-Miller et al. 2005). In fact, hypothalamic ARC activity of $G s k 3 \beta$ has been shown to be increased in HF-fed and HF/high-fructose-fed mice (Benzler et al. 2012, Anderson et al. 2013), whereas overexpression in the mediobasal hypothalamus has been shown to lead to hyperphagia and obesity in mice that were challenged with an HF diet (Benzler et al. 2012). The insulin receptor substrate 2 (IRS2) gene, another important modulator of insulin signalling, has been associated with severe human obesity (Lautier et al. 2003), whereas the central ablation of Irs 2 in mouse models has been shown to lead to obesity (Lin et al. 2004, Sadagurski et al. 2012). However, a recent study has shown an opposite phenotype, with obesity induced by an $\mathrm{HF} /$ high-fructose diet leading to an increase in Irs2 expression (Anderson et al. 2013). This may be in line with the present data, which indicates a $\sim 1$.3-fold increase in the DIO group as compared to the DR group. Finally, another two potential candidates are the epigenetic modifiers chromodomain helicase DNA binding protein 2 (Chd2) and SET domain containing (lysine methyltransferase) 8 (Setd8); the former is involved in chromatin remodelling, and the latter is involved in

Published by Bioscientifica Ltd. 

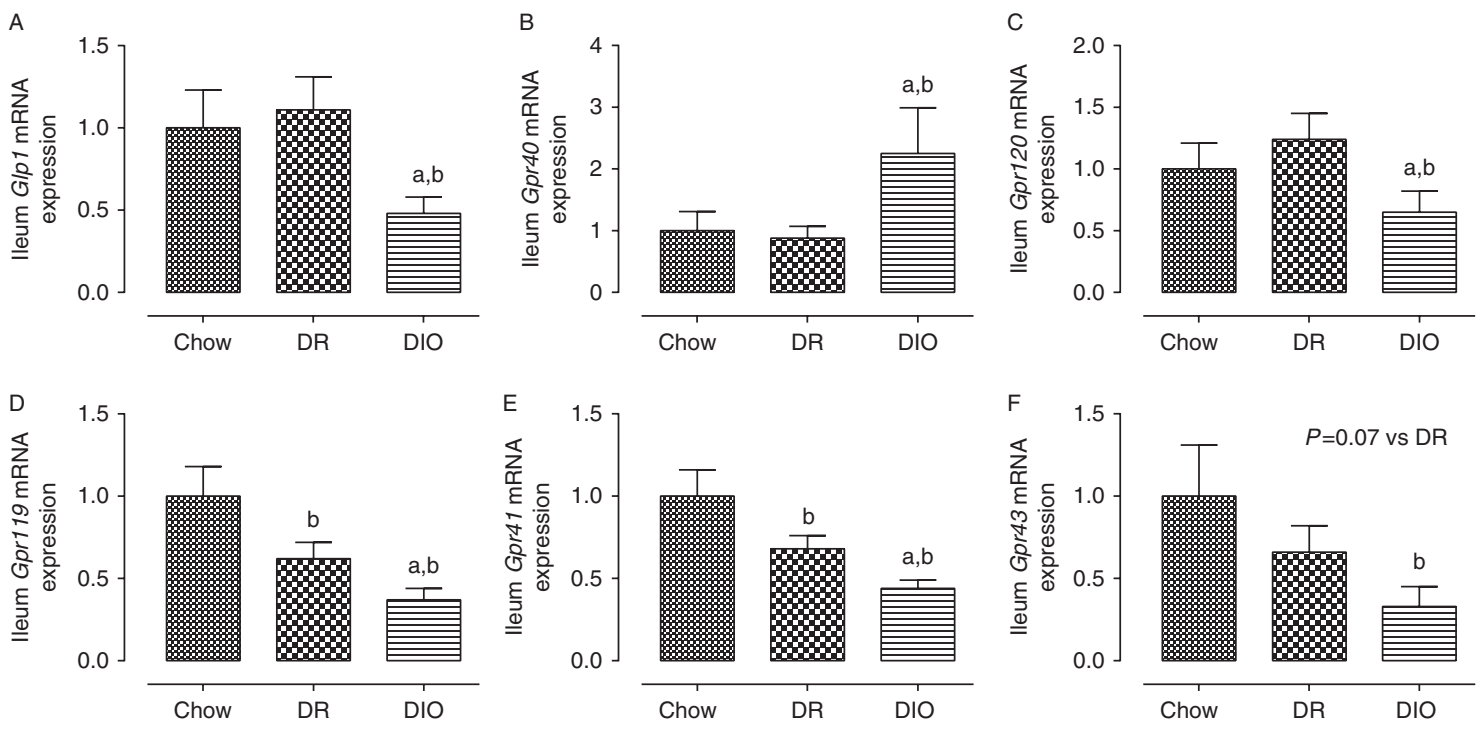

\section{Figure 6}

Peripheral mRNA expression levels of $G / p 1$ (A) and the fatty acid responsive receptors Gpr40 (B), Gpr120 (C), Gpr119 (D), Gpr41 (E) and Gpr43 (F) in whole ileal tissue from Chow, DR and DIO groups after 6 weeks of feeding.
$R n 18 s$ was used as the housekeeping gene. Results are presented as means \pm s.E.M. ( $n=8-13$ per group) relative to Chow mice. ${ }^{\mathrm{a}} P<0.05$ vs DR; ${ }^{\mathrm{b}} P<0.05$ vs Chow (one-way ANOVA). histone methylation. Both of these candidates were increased by 1.4- and 1.3-fold respectively in the present DIO mice. CHD2 has previously been associated with T2D in human subjects in two GWAS studies (Diabetes Genetics Initiative of Broad Institute of Harvard and MIT et al. 2007, Zeggini et al. 2007), and Chd2 was DE in a mouse model of HF-induced islet failure (Dreja et al. 2010). More recently, a study has shown increased whole-brain Chd2 expression in an obese congenic strain (Sarahan et al. 2011). Similarly, increased expression levels of Setd8 have been documented in the adipose tissue of both DIO and $o b / o b$ mouse models and was found to be regulated by Ppary; in these studies, adipogenesis occurred through chromatin modification (Wakabayashi et al. 2009, Okamura et al. 2010). Although these genes appear to be interesting potential candidates based on peripheral expression studies, more extensive work is required to identify their importance centrally and to determine whether they play a significant role in the differentiation between susceptibility and resistance.

Although hypothalamic regulation has always been viewed as the master controller of body weight, we cannot discount the importance of other central regions, including the brainstem. A recent study showed that exposure to HF during the perinatal period compromises the excitability and responsiveness of the gastric-projecting dorsal motor nucleus of the vagus (Bhagat et al. 2015). Furthermore, lateral pontine parabrachial nucleus leptin receptor activation leads to reduced food intake (Alhadeff et al. 2014). Thus, there may well be differences between DIO and DR mice in the way that peripheral signals (e.g. leptin, adiponectin, Glp1 and ghrelin) are processed in the hindbrain.

Of the major circulating factors, the adipokines leptin and adiponectin are key contributors to appetite and body weight regulation. As was expected, the present DIO mice showed elevated plasma leptin levels, and similar levels were seen between the DR and chow-fed mice. Interestingly, there appears to be a disconnect with gene expression levels: the DIO mice demonstrated similar expression to that of the chow-fed mice across all three fat depots, whereas the DR group displayed a twofold increase in infra-renal fat. This same difference between obesityprone and resistant mice has been reported previously in obese B6 vs lean A/J mice following HF feeding (Watson et al. 2000). However, the fact that our DIO mice have the same level of expression as the chow-fed mice implies that susceptibility is not associated with defects in leptin gene expression, which is similar to other findings (Ahren et al. 1997, Van Heek et al. 1997). This increase in plasma leptin is likely reflective of total fat mass. In contrast, the present finding of increased expression in DR mice has to our knowledge not been reported previously. With respect to adiponectin, which in obesity and insulin-resistant states 
is generally found to be reduced (Arita et al. 1999, Weyer et al. 2001), our DIO mice exhibited elevated plasma levels. However, there is some evidence to suggest that this is not always the case: one study showed no difference (Barnea et al. 2006), and another showed an increase in plasma levels (Perez-Echarri et al. 2005). At the gene level, adiponectin expression was reduced in the gonadal and infra-renal depots of the DIO mice, but there were no changes in the subcutaneous depot. Interestingly, the reports that have shown dissociation between obesity and plasma adiponectin also reported reduced adiponectin gene expression (Barnea et al. 2006), but they were not specific about the depot involved. Moreover, adiponectin is known to have an inverse relationship with the proinflammatory cytokine Tnfo; increased plasma adiponectin suppresses $\operatorname{Tn} f \alpha$ expression in adipose tissue (Maeda et al. 2002). The present results are also in line with this, in that they showed a reduction in Tnfo mRNA expression in the subcutaneous and infra-renal depots of the DIO mice. The DR mice, in contrast, had the same plasma adiponectin levels as the chow-fed mice and showed the same gene expression pattern of leptin, which suggests that the DR mice may experience increases in the amount of gene required to maintain the same plasma levels as the chow-fed group. Nonetheless, the present data collectively imply that adipose tissue may not be associated with susceptibility; rather, it may be an adaptive tissue in resistance.

A current focal area in the pathophysiology of obesity is the gut (Blad et al. 2012), which is responsible for the secretion of a number of hormones in response to nutrient intake and is important in appetite and body weight regulation. Whereas energy extraction and obesity have been associated with changes in the gut microbiome (Turnbaugh et al. 2006, 2008), the present study did not measure the microbiota profile of the mice or its metabolite by-products (such as long- and short-chain fatty acids). However, it is known that these by-products can affect the functional expression of intestinal nutrientresponsive Gpr and may suggest a role for gut microbiota in modulating satiation. Therefore, we measured ileal gene expression of Gpr40, Gpr120, Gpr119, Gpr41 and Gpr43, all of which are modulated by fatty acids. Gpr40 is known to be involved in the $\beta$-cell response of secreting insulin following fatty acid stimulation (Kebede et al. 2008), whereas all of these $G p r$ variants have been shown to be associated with Glp1 secretion from the gut (Hirasawa et al. 2005, Edfalk et al. 2008, Lauffer et al. 2009, Blad et al. 2012). However, little is known about the contribution of these receptors to diet-induced weight gain. The present data demonstrate that DIO mice have increased gut Gpr40 gene expression but reduced Gpr120 and Gpr119 expression relative to DR and chow-fed mice, and Gpr40 and Gpr120 were similarly expressed between the DR and chow-fed mice. Gpr41 also showed the same reduced expression pattern in the DIO mice, with a trend in Gpr43 expression. A study by Duca et al. (2012) reported similarly increased Gpr40 but reduced Gpr120 and Gpr41 gene expression in DIO rats as compared to DR rats; however, this was in response to an intragastric lipid load, and there were no chow-fed controls for comparison. The reduction in $\mathrm{Gpr}$ expression in the present study may also explain why we saw a reduction in Glp1 mRNA expression in our DIO mice. It is clear that Glp1 affects satiety by acting centrally (Lamont \& Andrikopoulos 2014), and the reduced gut expression of this incretin may well contribute to the increased energy intake of the DIO mice. Although it is not entirely clear why Gpr40 is markedly elevated in DIO mice, there may be a compensatory mechanism in place that activates this Gpr when the others are reduced. If and how this occurs is not known, however. The variable expression patterns that occur following exposure to the same diet could also infer polymorphic differences between DIO and DR mice in the transcriptional regulators of $G p r$. Although it is uncertain how these Gpr changes interact and contribute to the obese or resistant phenotype, what is evident is that receptor expression differences appear to be important in the ability of B6 mice to respond to incoming nutrients, which implies a significant role of the gut in diet-induced weight gain and weight gain resistance.

Although the present study is descriptive in nature, the fact remains that we still do not have a firm grasp on why genetically similar mice that consume the same HED diet in the same environment can have vastly different body weight gain responses. We have endeavoured to shed some light on this by reporting the greater involvement of peripheral pathways (fat and gut) than hypothalamic pathways. It is indeed an important exercise to provide such descriptive reports, seeing as dietary composition, length of diet intervention and even the sex of the animal used can provide different outcomes from those already published, as is evident by the present study. Nonetheless, we demonstrated that susceptibility and resistance to dietinduced obesity is quite complex, and given the increased interest in gut microbiota in the development of obesity and its associated comorbidities, the changes in $G p r$ that were demonstrated in the present study provide us with a novel and plausible mechanism by which these differences may occur.

Published by Bioscientifica Ltd. 


\section{Supplementary data}

This is linked to the online version of the paper at http://dx.doi.org/10.1530/ JOE-15-0131.

\section{Declaration of interest}

The authors declare that there is no conflict of interest that could be perceived as prejudicing the impartiality of the research reported.

\section{Funding}

This study was funded by seeding grants from the Diabetes Australia Research Trust (to B C F), the Sir Edward Dunlop Medical Research Foundation (to B C F), the Austin Health Medical Research Foundation (to B C F) and the University of Melbourne (to B C F) and by the National Health and Medical Research Council (app number 1060173).

\section{References}

Ahren B \& Scheurink AJ 1998 Marked hyperleptinemia after high-fat diet associated with severe glucose intolerance in mice. European Journal of Endocrinology 139 461-467. (doi:10.1530/eje.0.1390461)

Ahren B, Mansson S, Gingerich RL \& Havel PJ 1997 Regulation of plasma leptin in mice: influence of age, high-fat diet, and fasting. American Journal of Physiology 273 R113-R120.

Alhadeff AL, Hayes MR \& Grill HJ 2014 Leptin receptor signaling in the lateral parabrachial nucleus contributes to the control of food intake. American Journal of Physiology. Regulatory, Integrative and Comparative Physiology 307 R1338-R1344. (doi:10.1152/ajpregu.00329.2014)

Andersen G, Wegner L, Yanagisawa K, Rose CS, Lin J, Glumer C, Drivsholm T, Borch-Johnsen K, Jorgensen T, Hansen T et al. 2005 Evidence of an association between genetic variation of the coactivator PGC-1 $\beta$ and obesity. Journal of Medical Genetics 42 402-407. (doi:10.1136/jmg.2004. 026278)

Anderson RA, Qin B, Canini F, Poulet L \& Roussel AM 2013 Cinnamon counteracts the negative effects of a high fat/high fructose diet on behavior, brain insulin signaling and Alzheimer-associated changes. PLOS ONE 8 e83243. (doi:10.1371/journal.pone.0083243)

Arita Y, Kihara S, Ouchi N, Takahashi M, Maeda K, Miyagawa J, Hotta K, Shimomura I, Nakamura T, Miyaoka K et al. 1999 Paradoxical decrease of an adipose-specific protein, adiponectin, in obesity. Biochemical and Biophysical Research Communications 257 79-83. (doi:10.1006/bbrc. 1999.0255)

Barnea M, Shamay A, Stark AH \& Madar Z 2006 A high-fat diet has a tissuespecific effect on adiponectin and related enzyme expression. Obesity 14 2145-2153. (doi:10.1038/oby.2006.251)

Benzler J, Ganjam GK, Kruger M, Pinkenburg O, Kutschke M, Stohr S, Steger J, Koch CE, Olkrug R, Schwartz MW et al. 2012 Hypothalamic glycogen synthase kinase $3 \beta$ has a central role in the regulation of food intake and glucose metabolism. Biochemical Journal 447 175-184. (doi:10.1042/BJ20120834)

Bhagat R, Fortna SR \& Browning KN 2015 Exposure to a high fat diet during the perinatal period alters vagal motoneurone excitability, even in the absence of obesity. Journal of Physiology 593 285-303. (doi:10.1113/ jphysiol.2014.282806)

Blad CC, Tang C \& Offermanns S 2012 G protein-coupled receptors for energy metabolites as new therapeutic targets. Nature Reviews. Drug Discovery 11 603-619. (doi:10.1038/nrd3777)

Blundell JE, Stubbs RJ, Golding C, Croden F, Alam R, Whybrow S, Le Noury J \& Lawton CL 2005 Resistance and susceptibility to weight gain: individual variability in response to a high-fat diet. Physiology \& Behavior 86 614-622. (doi:10.1016/j.physbeh.2005.08.052)
Burcelin R, Crivelli V, Dacosta A, Roy-Tirelli A \& Thorens B 2002 Heterogeneous metabolic adaptation of C57BL/6J mice to high-fat diet. American Journal of Physiology. Endocrinology and Metabolism 282 E834-E842. (doi:10.1152/ajpendo.00332.2001)

Chang S, Graham B, Yakubu F, Lin D, Peters JC \& Hill JO 1990 Metabolic differences between obesity-prone and obesity-resistant rats. American Journal of Physiology 259 R1103-R1110.

Clodfelder-Miller B, De Sarno P, Zmijewska AA, Song L \& Jope RS 2005 Physiological and pathological changes in glucose regulate brain Akt and glycogen synthase kinase-3. Journal of Biological Chemistry $\mathbf{2 8 0}$ 39723-39731. (doi:10.1074/jbc.M508824200)

Diabetes Genetics Initiative of Broad Institute of Harvard and MIT, Lund University and Novartis Institutes of BioMedical Research , Saxena R, Voight BF, Lyssenko V, Burtt NP, de Bakker PI, Chen H \& Roix JJ 2007 Genome-wide association analysis identifies loci for type 2 diabetes and triglyceride levels. Science 316 1331-1336. (doi:10.1126/science. 1142358)

Dreja T, Jovanovic Z, Rasche A, Kluge R, Herwig R, Tung YC, Joost HG, Yeo GS \& Al-Hasani H 2010 Diet-induced gene expression of isolated pancreatic islets from a polygenic mouse model of the metabolic syndrome. Diabetologia 53 309-320. (doi:10.1007/s00125009-1576-4)

Duca FA, Swartz TD, Sakar Y \& Covasa M 2012 Decreased intestinal nutrient response in diet-induced obese rats: role of gut peptides and nutrient receptors. International Journal of Obesity 37 375-371. (doi:10.1038/ijo. 2012.45)

Edfalk S, Steneberg P \& Edlund H 2008 Gpr40 is expressed in enteroendocrine cells and mediates free fatty acid stimulation of incretin secretion. Diabetes 57 2280-2287. (doi:10.2337/db08-0307)

Enriori PJ, Evans AE, Sinnayah P, Jobst EE, Tonelli-Lemos L, Billes SK, Glavas MM, Grayson BE, Perello M, Nillni EA et al. 2007 Diet-induced obesity causes severe but reversible leptin resistance in arcuate melanocortin neurons. Cell Metabolism 5 181-194. (doi:10.1016/j.cmet. 2007.02.004)

Fam BC, Morris MJ, Hansen MJ, Kebede M, Andrikopoulos S, Proietto J \& Thorburn AW 2007 Modulation of central leptin sensitivity and energy balance in a rat model of diet-induced obesity. Diabetes, Obesity \& Metabolism 9 840-852. (doi:10.1111/j.1463-1326.2006.00653.x)

Fam B, Rose LJ, Sgambellone R, Ruan Z, Proietto J \& Andrikopoulos S 2012 Normal muscle glucose uptake in mice deficient in muscle glut-4. Journal of Endocrinology 214 313-327. (doi:10.1530/JOE-12-0032)

Funkat A, Massa CM, Jovanovska V, Proietto J \& Andrikopoulos S 2004 Metabolic adaptations of three inbred strains of mice (C57BL/6, DBA/2, and 129T2) in response to a high-fat diet. Journal of Nutrition $\mathbf{1 3 4}$ 3264-3269.

Hirasawa A, Tsumaya K, Awaji T, Katsuma S, Adachi T, Yamada M, Sugimoto Y, Miyazaki S \& Tsujimoto G 2005 Free fatty acids regulate gut incretin glucagon-like peptide-1 secretion through GPR120. Nature Medicine 11 90-94. (doi:10.1038/nm1168)

Huang XF, Han M, South T \& Storlien L 2003a Altered levels of POMC. AgRP and MC4-R mRNA expression in the hypothalamus and other parts of the limbic system of mice prone or resistant to chronic highenergy diet-induced obesity. Brain Research 992 9-19. (doi:10.1016/ j.brainres.2003.08.019)

Huang XF, Han M \& Storlien LH 2003b The level of NPY receptor mRNA expression in diet-induced obese and resistant mice. Brain Research. Molecular Brain Research 115 21-28. (doi:10.1016/S0169$328 \mathrm{X}(03) 00174-8)$

Kebede M, Alquier T, Latour MG, Semache M, Tremblay C \& Poitout V 2008 The fatty acid receptor GPR40 plays a role in insulin secretion in vivo after high-fat feeding. Diabetes 57 2432-2437. (doi:10.2337/ db08-0553)

Lamont BJ \& Andrikopoulos S 2014 Hope and fear for new classes of type 2 diabetes drugs: is there preclinical evidence that incretin-based therapies alter pancreatic morphology? Journal of Endocrinology 221 T43-T61. (doi:10.1530/JOE-13-0577) 
Lauffer LM, Iakoubov R \& Brubaker PL 2009 GPR119 is essential for oleoylethanolamide-induced glucagon-like peptide-1 secretion from the intestinal enteroendocrine L-cell. Diabetes 58 1058-1066. (doi:10.2337/db08-1237)

Lautier C, El Mkadem SA, Renard E, Brun JF, Gris JC, Bringer J \& Grigorescu F 2003 Complex haplotypes of IRS2 gene are associated with severe obesity and reveal heterogeneity in the effect of Gly1057Asp mutation. Human Genetics 113 34-43.

Leibel RL, Rosenbaum M \& Hirsch J 1995 Changes in energy expenditure resulting from altered body weight. New England Journal of Medicine 332 621-628. (doi:10.1056/NEJM199503093321001)

Levin BE \& Dunn-Meynell AA 2000 Defense of body weight against chronic caloric restriction in obesity-prone and -resistant rats. American Journal of Physiology. Regulatory, Integrative and Comparative Physiology 278 R231-R237.

Levin BE \& Dunn-Meynell AA 2002 Defense of body weight depends on dietary composition and palatability in rats with diet-induced obesity. American Journal of Physiology. Regulatory, Integrative and Comparative Physiology 282 R46-R54.

Levin BE, Triscari J, Hogan S \& Sullivan AC 1987 Resistance to diet-induced obesity: food intake, pancreatic sympathetic tone, and insulin. American Journal of Physiology 252 R471-R478.

Levin BE, Dunn-Meynell AA, Balkan B \& Keesey RE 1997 Selective breeding for diet-induced obesity and resistance in Sprague-Dawley rats. American Journal of Physiology 273 R725-R730.

Levine JA, Eberhardt NL \& Jensen MD 1999 Role of nonexercise activity thermogenesis in resistance to fat gain in humans. Science 283 212-214. (doi:10.1126/science.283.5399.212)

Li J, Ma W \& Wang S 2011 Slower gastric emptying in high-fat diet induced obese rats is associated with attenuated plasma ghrelin and elevated plasma leptin and cholecystokinin concentrations. Regulatory Peptides 171 53-57. (doi:10.1016/j.regpep.2011.07.004)

Lin X, Taguchi A, Park S, Kushner JA, Li F, Li Y \& White MF 2004 Dysregulation of insulin receptor substrate 2 in $\beta$ cells and brain causes obesity and diabetes. Journal of Clinical Investigation 114 908-916. (doi:10.1172/JCI22217)

MacLean PS, Higgins JA, Johnson GC, Fleming-Elder BK, Donahoo WT, Melanson EL \& Hill JO 2004 Enhanced metabolic efficiency contributes to weight regain after weight loss in obesity-prone rats. American Journal of Physiology. Regulatory, Integrative and Comparative Physiology 287 R1306-R1315. (doi:10.1152/ajpregu.00463.2004)

Maeda N, Shimomura I, Kishida K, Nishizawa H, Matsuda M, Nagaretani H, Furuyama N, Kondo H, Takahashi M, Arita Y et al. 2002 Diet-induced insulin resistance in mice lacking adiponectin/ACRP30. Nature Medicine 8 731-737. (doi:10.1038/nm724)

Mangiafico SP, Lim SH, Neoh S, Massinet H, Joannides CN, Proietto J, Andrikopoulos S \& Fam BC 2011 A primary defect in glucose production alone cannot induce glucose intolerance without defects in insulin secretion. Journal of Endocrinology 210 335-347. (doi:10.1530/ JOE-11-0126)

Marti A \& Ordovas J 2011 Epigenetics lights up the obesity field. Obesity Facts 4 187-190. (doi:10.1159/000329847)

Meirhaeghe A, Crowley V, Lenaghan C, Lelliott C, Green K, Stewart A, Hart K, Schinner S, Sethi JK, Yeo G et al. 2003 Characterization of the human, mouse and rat PGC1 $\beta$ (peroxisome-proliferator-activated receptor- $\gamma$ co-activator $1 \beta$ ) gene in vitro and in vivo. Biochemical Journal 373 155-165. (doi:10.1042/BJ20030200)

Okamura M, Inagaki T, Tanaka T \& Sakai J 2010 Role of histone methylation and demethylation in adipogenesis and obesity. Organogenesis 6 24-32. (doi:10.4161/org.6.1.11121)

O'Rahilly S 2009 Human genetics illuminates the paths to metabolic disease. Nature 462 307-314. (doi:10.1038/nature08532)

Pagliassotti MJ, Knobel SM, Shahrokhi KA, Manzo AM \& Hill JO 1994 Time course of adaptation to a high-fat diet in obesity-resistant and obesity-prone rats. American Journal of Physiology 267 R659-R664.
Patwari P, Emilsson V, Schadt EE, Chutkow WA, Lee S, Marsili A, Zhang Y, Dobrin R, Cohen DE, Larsen PR et al. 2011 The arrestin domain-containing 3 protein regulates body mass and energy expenditure. Cell Metabolism 14 671-683. (doi:10.1016/j.cmet.2011. 08.011)

Perez-Echarri N, Perez-Matute P, Martinez JA, Marti A \& Moreno-Aliaga MJ 2005 Serum and gene expression levels of leptin and adiponectin in rats susceptible or resistant to diet-induced obesity. Journal of Physiology and Biochemistry 61 333-342. (doi:10.1007/BF03167050)

Peyot ML, Pepin E, Lamontagne J, Latour MG, Zarrouki B, Lussier R, Pineda M, Jetton TL, Madiraju SR, Joly E et al. $2010 \beta$-cell failure in diet-induced obese mice stratified according to body weight gain: secretory dysfunction and altered islet lipid metabolism without steatosis or reduced $\beta$-cell mass. Diabetes 59 2178-2187. (doi:10.2337/ db09-1452)

Ravussin E \& Bouchard C 2000 Human genomics and obesity: finding appropriate drug targets. European Journal of Pharmacology $\mathbf{4 1 0} 131-145$. (doi:10.1016/S0014-2999(00)00811-6)

Sadagurski M, Leshan RL, Patterson C, Rozzo A, Kuznetsova A, Skorupski J, Jones JC, Depinho RA, Myers MG Jr \& White MF 2012 IRS2 signaling in LepR-b neurons suppresses FoxO1 to control energy balance independently of leptin action. Cell Metabolism 15 703-712. (doi:10.1016/j.cmet.2012.04.011)

Sarahan KA, Fisler JS \& Warden CH 2011 Four out of eight genes in a mouse chromosome 7 congenic donor region are candidate obesity genes. Physiological Genomics 43 1049-1055. (doi:10.1152/physiolgenomics. 00134.2010)

Steinberg GR, Watt MJ, Fam BC, Proietto J, Andrikopoulos S, Allen AM, Febbraio MA \& Kemp BE 2006 Ciliary neurotrophic factor suppresses hypothalamic AMP-kinase signaling in leptin-resistant obese mice. Endocrinology 147 3906-3914. (doi:10.1210/en.2005-1587)

Thorburn AW, Holdsworth A, Proietto J \& Morahan G 2000 Differential and genetically separable associations of leptin with obesity-related traits. International Journal of Obesity and Related Metabolic Disorders 24 742-750. (doi:10.1038/sj.ijo.0801213)

Torri C, Pedrazzi P, Leo G, Muller EE, Cocchi D, Agnati LF \& Zoli M 2002 Diet-induced changes in hypothalamic pro-opio-melanocortin mRNA in the rat hypothalamus. Peptides 23 1063-1068. (doi:10.1016/ S0196-9781(02)00030-X)

Turnbaugh PJ, Ley RE, Mahowald MA, Magrini V, Mardis ER \& Gordon JI 2006 An obesity-associated gut microbiome with increased capacity for energy harvest. Nature $\mathbf{4 4 4} 1027-1031$. (doi:10.1038/ nature05414)

Turnbaugh PJ, Backhed F, Fulton L \& Gordon JI 2008 Diet-induced obesity is linked to marked but reversible alterations in the mouse distal gut microbiome. Cell Host \& Microbe 3 213-223. (doi:10.1016/j.chom.2008. 02.015)

Van Heek M, Compton DS, France CF, Tedesco RP, Fawzi AB, Graziano MP, Sybertz EJ, Strader CD \& Davis HR Jr 1997 Diet-induced obese mice develop peripheral, but not central, resistance to leptin. Journal of Clinical Investigation 99 385-390. (doi:10.1172/JCI119171)

Visinoni S, Khalid NF, Joannides CN, Shulkes A, Yim M, Whitehead J, Tiganis T, Lamont BJ, Favaloro JM, Proietto J et al. 2012 The role of liver fructose-1,6-bisphosphatase in regulating appetite and adiposity. Diabetes 61 1122-1132. (doi:10.2337/db11-1511)

Wakabayashi K, Okamura M, Tsutsumi S, Nishikawa NS, Tanaka T, Sakakibara I, Kitakami J, Ihara S, Hashimoto Y, Hamakubo T et al. 2009 The peroxisome proliferator-activated receptor $\gamma /$ retinoid $\mathrm{X}$ receptor $\alpha$ heterodimer targets the histone modification enzyme PR-Set7/Setd8 gene and regulates adipogenesis through a positive feedback loop. Molecular and Cellular Biology 29 3544-3555. (doi:10.1128/MCB. 01856-08)

Watson PM, Commins SP, Beiler RJ, Hatcher HC \& Gettys TW 2000 Differential regulation of leptin expression and function in $\mathrm{A} / \mathrm{J}$ vs C57BL/6J mice during diet-induced obesity. American Journal of Physiology. Endocrinology and Metabolism 279 E356-E365. 
Weyer C, Funahashi T, Tanaka S, Hotta K, Matsuzawa Y, Pratley RE \& Tataranni PA 2001 Hypoadiponectinemia in obesity and type 2 diabetes: close association with insulin resistance and hyperinsulinemia. Journal of Clinical Endocrinology and Metabolism $\mathbf{8 6}$ 1930-1935. (doi:10.1210/jcem.86.5.7463)

Wong N, Fam BC, Cempako GR, Steinberg GR, Walder K, Kay TW, Proietto J $\&$ Andrikopoulos S 2011 Deficiency in interferon- $\gamma$ results in reduced body weight and better glucose tolerance in mice. Endocrinology 152 3690-3699. (doi:10.1210/en.2011-0288)
Zeggini E, Weedon MN, Lindgren CM, Frayling TM, Elliott KS, Lango H, Timpson NJ, Perry JR, Rayner NW, Freathy RM et al. 2007 Replication of genome-wide association signals in UK samples reveals risk loci for type 2 diabetes. Science 316 1336-1341. (doi:10.1126/science. 1142364)

Ziotopoulou M, Mantzoros CS, Hileman SM \& Flier JS 2000 Differential expression of hypothalamic neuropeptides in the early phase of dietinduced obesity in mice. American Journal of Physiology. Endocrinology and Metabolism 279 E838-E845.

Received in final form 23 April 2015

Accepted 30 April 2015

Accepted Preprint published online 1 May 2015
Published by Bioscientifica Ltd. 